\title{
The Community of Parasites Infecting Clarias gariepinus in the Tanzanian Waters: A Case of Lake Victoria
}

\author{
Chacha John Mwita \\ Department of Aquatic Science and Fisheries, University of Dar es Salaam, Dar es Salaam, Tanzania \\ Email: mwitachacha@udsm.ac.tz
}

Received 18 August 2014; revised 18 September 2014; accepted 25 September 2014

Copyright (C) 2014 by author and Scientific Research Publishing Inc.

This work is licensed under the Creative Commons Attribution International License (CC BY).

http://creativecommons.org/licenses/by/4.0/

(c) (i) Open Access

\begin{abstract}
Quantitative variations in parasites were investigated with respect to sex and size of Clarias gariepinus, season and localities sampled. Parasitic infection in male and female fish was not significantly different; prevalence (Man-Whitney paired sample test, $U=135.5, p=0.7697$ ), mean intensity $(U=136, p=0.7829)$. Based on Kruskal-Wallis test analysis, the prevalence and mean intensity of five parasite species varied significantly among the three localities sampled. Adult parasites in Clarias gariepinus showed high abundance during the dry season while the larval forms showed high abundance in the wet season. In most of the parasite species analyzed the abundance varied significantly with host size. The abundance of Dolops ranarum, Paracamallanus cyatopharynx and Eumasenia bangweulensis for instance, increased with fish size, while that of Diplostomum mashonense, Tylodelphys species, Astiotrema reniferum, piscicolid leeches and Monobothrioides woodlandi increased initially but decreased as fish length reached $31-40 \mathrm{~cm}$. Total parasite burden increased in fish of $20-40 \mathrm{~cm}$ standard length. Generally, most parasites were highly overdispersed and the negative binomial model described their distribution.
\end{abstract}

\section{Keywords}

Population Biology, Parasites, Clarias gariepinus, Lake Victoria, Tanzania

\section{Introduction}

Fish provides the necessary proteins for human health worldwide. In Tanzania specifically Lake Victoria, communities rely on catfishes as one of the major protein sources. The catfishes are members of the order Siluriformes and comprise about 2800 species worldwide [1]. There are three families in the African suborder Silu- 
roidea that contain species suitable for aquaculture. These are the Claroteidae (formerly Bagridae), the Schilbeidae and the Clariidae. In Tanzania, the family Clariidae has six genera with 21 representative species that occupy varying habitats in streams, rivers and lakes [2]. Lake Victoria alone has three genera with six species namely: Clarias gariepinus (Burchell, 1822), Clarias werneri (Boulenger, 1906), Clarias alluaudi (Boulenger, 1906), Clarias liocephalus (Boulenger, 1898), Clariallabes petricola (Greenwood, 1956) and Xenoclarias eupogon. Dinotoptera and Bathyclarias are endemic to Lakes Tanganyika and Malawi, respectively [3].

Several comprehensive reviews of parasites of Clarias gariepinus from Lake Victoria basin are available [4]-[6]. Many data on the systematics of the parasites of Clarias gariepinus from the continental Africa and elsewhere are available in scientific papers [7]-[9]. However, studies dealing with quantitative data and ecology on C. gariepinus in Lake Victoria basin are still scarce. In addition, among the clariids, parasites of C. gariepinus are so far the only extensively studied while those of other species in the family are poorly known.

In the present paper the metazoan parasite fauna of Clarias gariepinus from the Mwanza Gulf, Lake Victoria (Figure 1) is discussed. It is anticipated that the study will show the abundance, distribution and seasonality of parasites in the localities surveyed.

\section{Materials and Methods}

\subsection{Study Site}

Figure 1 illustrates the area where this study took place. Sampling was carried out at three sites along the Mwanza Gulf namely, Butimba/Kirumba bays (BK), Nyegezi bay (N) and Lake Malimbe (LM) along Luanso bay. The two sites, Butimba/Kirumba and Nyegezi bays form a continuum along the shore of the gulf and therefore bear the features of the main lake. Nyegezi bay is located at $2^{\circ} 35$ 'S, $32^{\circ} 55^{\prime} \mathrm{E}$. The eastern part of Nyegezi bay is muddy and is fringed by abundant vegetation. It is relatively shallow with a maximum depth of nearly 9 $\mathrm{m}$ in some parts. A single seasonal stream empties into the eastern part of the bay. The western shore is mainly sandy and rocky.

Butimba/Kirumba bays are located at the entrance of the gulf, most part of which is sandy and rocky and along the shores are industries and human habitats. Two streams enter the lake via these bays; Mirongo empties into Kirumba bay and Malama into the eastern part of Butimba bay. The bottom at the mouth of these streams is mainly muddy and fringed by vegetation cover.

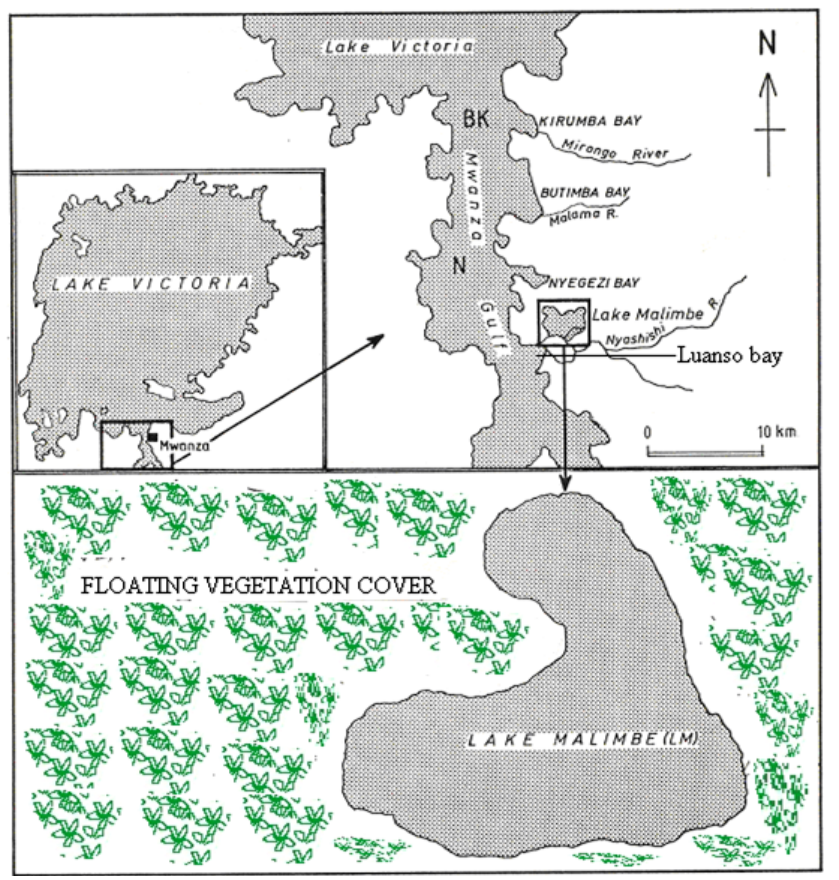

Figure 1. The Mwanza Gulf showing the three localities sampled [Butimba/Kirumba bays (BK), Nyegezi bay (N) and Lake Malimbe (LM)]. 
Lake Malimbe ( $\left.2^{\circ} 34.471^{\prime} \mathrm{S}, 32^{\circ} 53.867^{\prime} \mathrm{E}\right)$ adjoins Lake Victoria, located about $10 \mathrm{~km}$ from Mwanza town, off the eastern part of the Mwanza Gulf. It is a satellite lake, with a surface area of about $10 \mathrm{~km}^{2}$. Floating macrophytes such as Papyrus and Phragmites cover most of the lake. The remaining open water area is about $0.5 \mathrm{~km}^{2}$ with a maximum depth of $2.5 \mathrm{~m}$. Entry to the Lake is very difficult especially during the rainy season. There are no tributaries from the main lake and the main source of water is from seepage and rain run off. The bottom of the lake is essentially muddy. During much of the year (perhaps most years) Malimbe is cut off from the main lake. Connection is re-established in the rainy season from March-May particularly in years with exceptionally heavy rains like the El Ninõ of 1998.

\subsection{Methods}

Initially, 2004-2006, the study was intensive being sponsored by the Lake Victoria Environmental Management Project (LVEMP) and samples were collected twice per year i.e. wet (November to May) and dry (June to October) season. Later, 2007 to 2013, this was a monitoring period sponsored by Lake Victoria Research Initiative (VicRes); samples were collected once per year alternating between wet and dry seasons. About 18 - 50 fish depending on the availability were examined per every visit. Fish were caught by longlines and handlines with baited hooks. Dead fish were transported in an ice-cooled box and live fish in buckets filled with water from the lake to the laboratory. Examination of fish for parasites, handling and processing of parasites followed standard procedures as described by Moravec et al. [10] [11].

Comparison of abundance in relation to locality was analyzed by Kruskal-Wallis test. Comparison of abundance in relation to sex and size of the host were analyzed by Man-Whitney paired sample test and KruskalWallis test, respectively. Seasonality of parasites distribution and abundance were analyzed by Friedman's test [12]. Friedman's test was done by Statistica Package Version 9 (2009) while Kruskal-Wallis and Man-Whitney tests (U) were done using Instat Version 3.1. Most of the parasite's count data did not fit in the normality test and hence nonparametric test were employed in this study. Ecological terms are as defined by Margolis et al. [13].

\section{Results}

\subsection{Parasite Abundance in Relation to Sex}

The abundance of parasites between male and female fish were not significantly different, prevalence (ManWhitney tests, $\mathrm{U}=135.5, p=0.7697)$, mean intensity $(\mathrm{U}=136, p=0.7829)$. Table 1 is a summary of the results for $C$. gariepinus sampled for the period stated. The results show that relatively more female than male fish were infected by most parasites though mean intensity was considerably higher in male than in female fish. The number of female fish examined from each locality did not differ from that of male fish $(\mathrm{t}=1.85, p=0.082)$. Due to the similarities observed, the data for both male and female fish were pooled in subsequent analysis.

\subsection{The Abundance of Parasites with Respect to Localities}

The abundance of five parasite species was significantly different among the three localities sampled. The digenean D. mashonense was more abundant at Nyegezi bay than at Butimba/Kirumba bays and Lake Malimbe. Tylodelphys species, $P$. clarias, $M$. woodlandi and P. cyathopharynx were more abundant at Lake Malimbe than at Butimba/Kirumba and Nyegezi bays. D. ranarum was only observed in Lake Malimbe while piscicolid leeches and Eustrongyloides species only from Nyegezi bay. Proteocephalus species was found only from Butimba/Kirumba bays (Table 2).

\subsection{Seasonal Variation of Parasites Abundance}

Although most parasites occurred in all the localities, marked differences in the pattern of occurrence were observed. D. mashonense, Tylodelphys species, P. clarias and P. cyathopharynx occurred consistently in the three localities throughout the study period, except some few months at Butimba/Kirumba bays. The prevalence of $D$. mashonense varied during the study period as was at Nyegezi and Butimba/Kirumba bays when the occurrence of the digenean fell below 76\%. However, the variations were not statistically significant (Friedman's test $\chi^{2}=$ 2.97, $p=0.227)$, as was P. clarias $\left(\chi^{2}=3.5, p=0.174\right)$. Prevalence of Tylodelphys species $\left(\chi^{2}=104, p=0.005\right)$ and $P$. cyathopharynx $\left(\chi^{2}=19.45, p=0.001\right)$ varied significantly during the study period. In general, prevalence 
Table 1. Mean intensity (in parentheses) and prevalence of parasites in male and female Clarias gariepinus in Mwanza Gulf, Lake Victoria (Pooled data).

\begin{tabular}{|c|c|c|c|c|}
\hline Parasite & $\mathrm{n}_{\mathrm{f}}$ & Female & $\mathrm{n}_{\mathrm{m}}$ & Male \\
\hline Diplostomum mashonense & 515 & $87.88(536.36)$ & 426 & $87.84(540.83)$ \\
\hline Tylodelphys sp. & 181 & 30.89 (93.30) & 146 & $30.10(104.62$ \\
\hline Dolops ranarum & 20 & $3.41(3.10)$ & 14 & $2.89(3.64)$ \\
\hline Spinitectus petterae & 5 & $0.85(4.40)$ & 9 & $1.86(3.33)$ \\
\hline Procamallanus laevionchus & 12 & $2.05(2.08)$ & 11 & $2.27(2.45)$ \\
\hline Polyonchobothrium clarias & 178 & $30.38(2.70)$ & 146 & $30.10(2.86)$ \\
\hline Astiotrema reniferum & 29 & $4.95(5.62)$ & 30 & $6.19(5.67)$ \\
\hline Allocreadium mazoensis & 15 & $2.56(5.20)$ & 22 & $4.54(8.32)$ \\
\hline Piscicolid leeches & 12 & $2.05(3.50)$ & 17 & 3.51 (3.29) \\
\hline Monobothrioides woodlandi & 37 & $6.31(5.0)$ & 29 & $5.98(14.76)$ \\
\hline Paracamallanus cyatopharynx & 168 & $28.67(3.11)$ & 161 & $33.20(4.06)$ \\
\hline Contracaecum sp. & 28 & $4.78(14.57)$ & 19 & $3.92(25.84)$ \\
\hline Euclinostomum sp. & 5 & $0.85(9.60)$ & 5 & $1.03(6.80)$ \\
\hline Gyrodactylus sp. & 31 & $5.29(5.10)$ & 24 & 4.95 (3.63) \\
\hline Eumasenia bangweulensis & 32 & $5.46(5.81)$ & 30 & $6.19(5.77)$ \\
\hline Eustrongyloides sp. & - & - & 1 & $0.21(1)$ \\
\hline Proteocephulus sp. & - & - & 1 & $1.44(7)$ \\
\hline Total No. of fish examined & 586 & & 485 & \\
\hline
\end{tabular}

of most autogenic parasites was high during the dry season but declined in the rainy season. Prevalence of allogenic species such as Tylodelphys species and Contracaecum species were high in the rain season. Monthly variation in mean intensity showed no consistent pattern during the study period. However, for most autogenic parasites the highest mean intensity was recorded during the dry season and that of allogenic parasites increased during the rainy season.

\subsection{Seasonal Variation of the Variance to Mean Ratio}

All parasites recorded from C. gariepinus were overdispersed. The dispersion index (variance to mean ratio) among localities was not significant. The degree of overdispersion fluctuated in the same pattern as the prevalence and intensity of infection. The dispersion index also indicated that the number of heavily infected fish increased in the wet season for parasites using C. gariepinus as intermediate host, and the rise in infection was high in dry season for parasites using C. gariepinus as a definitive host. Some of the parasites however, did not show a consistent pattern probably due to low number of hosts infested.

\subsection{Prevalence of Parasites with Respect to the Length of $C_{n}$ gariepinus}

Prevalence of parasites in each size group of fish is shown in Table 3. In most of the parasite species analyzed prevalence varied significantly with host size. The prevalence of $D$. ranarum, $P$. cyathopharynx and E. bangweulensis increased with fish size. The prevalence of $D$. mashonense, Tylodelphys species, A. reniferum, piscicolid leeches and $M$. woodlandi increased initially but decreased as fish length reached $31-40 \mathrm{~cm}$. The remaining parasite species did not show a recognizable pattern. 
Table 2. Mean intensity (in parentheses) and prevalence of parasites on Clarias gariepinus from Mwanza Gulf, Lake Victoria.

\begin{tabular}{|c|c|c|c|c|}
\hline Parasite & Butimba/Kirumba & Nyegezi & Malimbe & Rmk \\
\hline Diplostomum mashonense & $(420.7 \mathrm{~A}) 85.2 \mathrm{~A}$ & $(716.1 \mathrm{~B}) 86.4 \mathrm{~A}$ & (461.7A) 91.2A & * \\
\hline Tylodelphys sp. & $(58.9 \mathrm{~A}) 8.05 \mathrm{~A}$ & (158.5B) 23.7B & (77.8A) 53.9C & * \\
\hline Dolops ranarum & - & - & (3.5) 8.06 & - \\
\hline Spinitectus petterae & (1.5) 2.67 & (1.9) 2.66 & (3.0) 0.50 & ns \\
\hline Procamallanus laevionchus & (1.0) 2.67 & (3.0) 1.06 & (2.24) 4.28 & ns \\
\hline Polyonchobothrium clarias & $(2.77 \mathrm{~A}) 31.5 \mathrm{~A}$ & $(2.48 \mathrm{~A}) 21.01 \mathrm{~B}$ & $(2.90 \mathrm{~A}) 38.04 \mathrm{~A}$ & * \\
\hline Astiotrema reniferum & (7.0) 8.05 & (1.67) 8.79 & (5.0) 8.06 & ns \\
\hline Allocreadium mazoensis & (10) 3.69 & (8.5) 3.72 & (12.67) 3.02 & ns \\
\hline Piscicolid leeches & - & (1.56) 6.12 & - & - \\
\hline Monobothrioides woodlandi & $(2.17 \mathrm{~A}) 4.03 \mathrm{~A}$ & $(3.5 \mathrm{~A}) 0.53 \mathrm{~B}$ & (11.15B) 13.1C & $* * *$ \\
\hline Paracamallanus cyatopharynx & $(2.31 \mathrm{~A}) 15.77 \mathrm{~A}$ & $(1.93 \mathrm{~A}) 20.47 \mathrm{~B}$ & $(4.46 \mathrm{~B}) 15.6 \mathrm{~A}$ & $* * *$ \\
\hline Contracaecum sp. & (9.9) 4.03 & (9.94) 4.52 & (13.9) 4.53 & ns \\
\hline Euclinostomum sp. & (3.0) 0.34 & (2.0) 0.80 & (3.17) 1.51 & ns \\
\hline Gyrodactylus sp. & (2.62) 4.36 & (2.32) 5.9 & (3.39) 4.53 & ns \\
\hline Eumasenia bangweulensis & (4.0) 5.34 & (6.79) 6.38 & (5.02) 9.52 & ns \\
\hline Eustrongyloides sp. & - & (1.0) 0.27 & - & - \\
\hline Proteocephulus sp. & (7.0) 0.34 & - & - & - \\
\hline Total No. of fish examined & 298 & 376 & 397 & \\
\hline
\end{tabular}

Kruskal-Wallis test, $p>0.05$, considered not significant. ${ }^{*}$ Significant; ${ }^{* *}$ Very significant; ${ }^{* * *}$ Extremely significant and "ns": not significant. Figures with different letters are statistically different.

\subsection{Mean Intensity of Parasites According to the Length $C$ gariepinus}

Mean intensity was calculated for each parasite species within each fish size group. The data obtained were compared using Kruskal-Wallis test. For most parasite species mean intensity varied significantly among fish of different sizes. For $D$. mashonense, Tylodelphys species and $M$. woodlandi for instance, mean intensity increased as the fish size increased but decreased in fish over $31-40 \mathrm{~cm}$ long. In other parasites, $P$. clarias, $D$. ranarum, $P$. cyathopharynx, E. bangweulensis and A. mazoensis, mean intensity increased as fish size increased without a decline in fish over $31-40 \mathrm{~cm}$. In some parasites, the rise in mean intensity observed was not consistent, as there was an initial rise followed by a decline and a rise again.

The mean number of parasites irrespective of species, excluding D. mashonense and Tylodelphys species increased with fish size up to 31 - $40 \mathrm{~cm}$ size class and declined thereafter (Figure 2). The mean number of parasite species per fish increased in the first group of fish size, remained constant in the subsequent three groups before declining to 6 species in fish over $40 \mathrm{~cm}$ standard length (Figure 3).

\subsection{Variation of Frequency Distribution with the Length of $C_{\text {s }}$ gariepinus}

The distribution of the intensity of infection of parasites in C. gariepinus showed that the zero class was the greatest in most parasites except in $D$. mashonense where the zero class was always smaller than the next class in the series. The number of hosts with low intensity of parasites was always higher than the number of heavily infected hosts. The distribution of the intensity of parasites was aggregated; hence the negative binomial fitted the distribution of all parasites analyzed. 
Table 3. Prevalence of parasites according to the length of $C$. gariepinus.

\begin{tabular}{ccccccc}
\hline Parasite & $4-10 \mathrm{~cm}$ & $11-20 \mathrm{~cm}$ & $21-30 \mathrm{~cm}$ & $31-40 \mathrm{~cm}$ & $<40 \mathrm{~cm}$ & $\mathrm{Rmk}$ \\
\hline Diplostomum mashonense & 66.18 & 87.95 & 92.17 & 91.74 & 85.88 & $\mathrm{~ns}$ \\
Tylodelphys sp. & $22.06 \mathrm{~A}$ & $29.75 \mathrm{~A}$ & $37.95 \mathrm{~B}$ & $33.03 \mathrm{~A}$ & $22.35 \mathrm{~A}$ & $*$ \\
Dolops ranarum & 0 & $0.56 \mathrm{~A}$ & $0.60 \mathrm{~A}$ & $9.17 \mathrm{~B}$ & $11.76 \mathrm{~B}$ & $*$ \\
Spinitectus petterae & 0 & 1.51 & 3.01 & 0.46 & 1.18 & $\mathrm{~ns}$ \\
Procamallanus laevionchus & 1.47 & 1.13 & 3.61 & 3.21 & 3.53 & $\mathrm{~ns}$ \\
Polyonchobothrium clarias & $26.47 \mathrm{~A}$ & $32.58 \mathrm{~B}$ & $36.14 \mathrm{~B}$ & $23.85 \mathrm{~A}$ & $24.71 \mathrm{~A}$ & $*$ \\
Astiotrema reniferum & 0 & $2.26 \mathrm{~A}$ & $4.22 \mathrm{~A}$ & $14.22 \mathrm{~B}$ & $10.59 \mathrm{~B}$ & $*$ \\
Allocreadium mazoensis & 0 & $1.13 \mathrm{~A}$ & $9.64 \mathrm{~B}$ & $4.13 \mathrm{C}$ & $7.06 \mathrm{~B}$ & $*$ \\
Piscicolid leeches & 0 & $3.77 \mathrm{~A}$ & $4.82 \mathrm{~A}$ & $0.46 \mathrm{~B}$ & 0 & $*$ \\
Monobothrioides woodlandi & $1.47 \mathrm{~A}$ & $1.51 \mathrm{~A}$ & $4.82 \mathrm{~A}$ & $17.43 \mathrm{~B}$ & $12.94 \mathrm{~B}$ & $*$ \\
Paracamallanus cyatopharynx & $2.94 \mathrm{~B}$ & $25.42 \mathrm{~A}$ & $34.94 \mathrm{~A}$ & $44.05 \mathrm{~A}$ & $43.53 \mathrm{~A}$ & $* *$ \\
Contracaecum sp. & 5.88 & 4.33 & 4.82 & 3.21 & 5.88 & $\mathrm{~ns}$ \\
Euclinostomum sp. & $1.47 \mathrm{~A}$ & $0.38 \mathrm{~B}$ & $0.60 \mathrm{~B}$ & $2.75 \mathrm{~A}$ & 0 & $*$ \\
Gyrodactylus sp. & $5.88 \mathrm{~A}$ & $4.14 \mathrm{~A}$ & $10.24 \mathrm{~B}$ & $5.50 \mathrm{~A}$ & 0 & $*$ \\
Eumasenia bangweulensis & $2.94 \mathrm{~A}$ & $3.95 \mathrm{~A}$ & $3.01 \mathrm{~A}$ & $7.80 \mathrm{~B}$ & $18.82 \mathrm{~B}$ & $*$ \\
Eustrongyloides sp. & 0 & 2.5 & 0 & 0 & 0 & - \\
Proteocephulus sp. & 0 & 0 & 0 & 0 & 3.0 & - \\
Total No. of fish examined & 68 & 531 & 166 & 218 & 85 & \\
\hline
\end{tabular}

"Significant; ${ }^{* *}$ Very significant; ${ }^{* * *}$ Extremely significant; "ns": Not significant, $p>0.05$, considered not significant. Figures with different letters are statistically different.

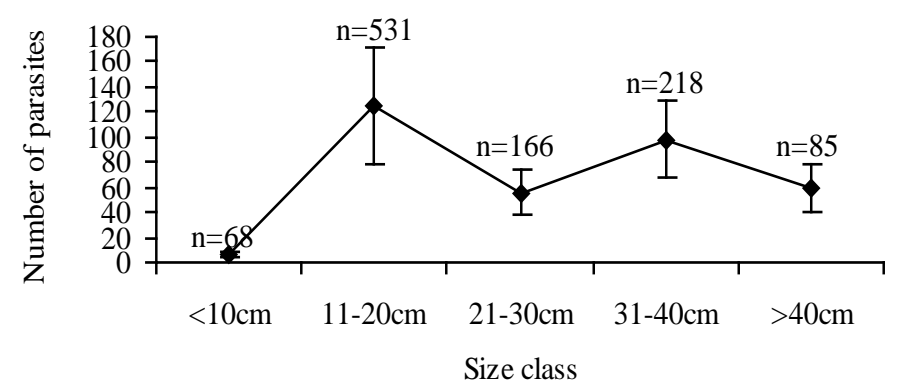

Figure 2. Mean number of parasites per fish, irrespective of species according to fish size (excluding D. mashonense and Tylodelphys sp.) (Error bars are $\pm \mathrm{SD}$ ).

The behaviour of the index of dispersion (Variance: mean ratio) with the length of $C$. gariepinus like mean intensity fell into two categories; in the first group there was an initial rise as fish size increased, followed by a decline in the fish over $40 \mathrm{~cm}$ standard length (D. mashonense, Tylodelphys sp. and $M$. woodlandi). The second category showed continuous increase in the dispersion index as the fish increased in size.

\section{Discussion}

\subsection{Abundance of Parasites According to the Sex of C. gariepinus}

The present study suggests that male and female C. gariepinus do occupy the same ecological guild and hence 


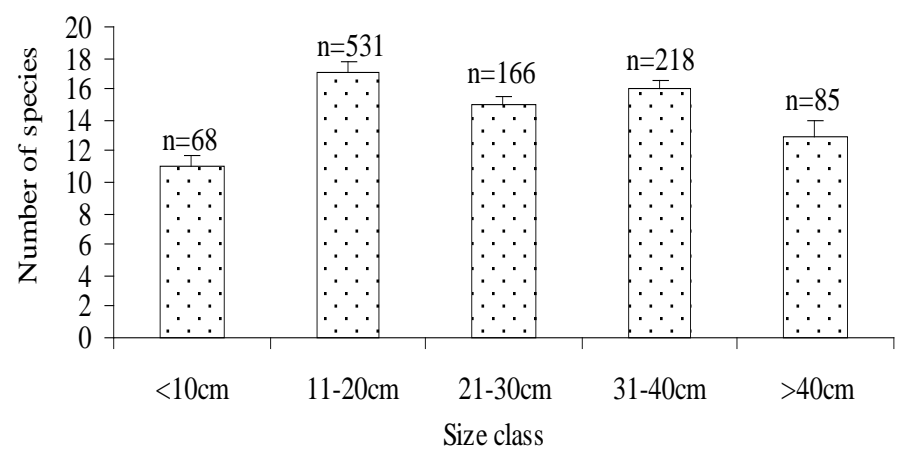

Figure 3. The number of parasite species per fish according to the length of C. gariepinus (Error bars are $\pm \mathrm{SD}$ ).

the prevalence and mean intensity of their parasite fauna were found to be similar. Similar studies found the same results [14]. Furthermore, it has been found that female vertebrates are less heavily infected with parasites than males [15]. Elevated levels of oestrogen are believed to protect female hosts from parasitic infections [16]. On the other hand Reimchen [17] suggested that competition for mates and subsequent elevation of testosterone levels could lead to immunosuppression in male hosts, hence an increase in susceptibility to parasitic infections. This could account for the relatively high mean intensity values observed in male as compared to female C. gariepinus in the present study.

\subsection{Variation of Parasite Abundance among the Three Localities Surveyed}

Previous studies have revealed variation in prevalence of parasites of fishes among lakes [18], rivers [19] and among sampling stations in large bodies of water [20]. The present study, like previous studies cited above, has demonstrated the existence of variation of prevalence and mean intensity of parasites in the same host species from different localities in the same lake. The variation observed indicates the presence of an uneven distribution in terms of species and density [21] of parasites intermediate hosts, some of which constitute food items for C. gariepinus among the localities surveyed [22]. This further affects the type and quantity of food materials taken by C. gariepinus, consequently differences in prevalence and mean intensity of parasites recruited among the three localities.

\subsection{Abundance of Parasites According to the Length of $C_{n}$ gariepinus}

Host size is suggested as the most important predictor of parasite load [21]. In the present study, two patterns were observed between parasites prevalence and mean intensity on the one hand and fish length on the other. The first pattern showed an initial rise in prevalence and mean intensity followed by a decrease in large fish. This is by far, the most commonly observed pattern in parasitological studies [23]. In the second pattern prevalence and mean intensity increased continuously with increasing length of $C$. gariepinus. The second pattern is similar to the first but differs due to low representation of large fish in samples.

In fish populations, the intensity of infection by metazoan parasites increases with the size of fish as observed in the present study. The increase sometimes stops beyond a certain host size, but the positive relationship generally holds when several classes are pooled. Large fish provide more internal space for parasite establishment and incur higher infection rates as they eat more parasitized prey [24]. Several biological parameters or ecological processes can determine which types of parasites are likely to correlate closely with host size. Density-dependent regulation of parasite numbers, for instance, may obscure the relationship between fish size and intensity of infection by preventing the accumulation of large numbers of parasites even in the largest fish [25]. Another example is the differences in the life span exhibited by different parasite taxa within a fish host; this could result in different rates of parasite accumulation as a function of fish size. Larval digeneans, for example, are long-lived in fish hosts and tend to accumulate over time and hence for these parasites intensity tends to correlate with fish size [24].

In the present study, it was observed that prevalence and mean intensity of the ectoparasites (D. ranarum, piscicolid leeches and Gyrodactylus species) and those of larval trematodes (D. mashonense, Tylodelphys species 
and Clinostomum species) increased with the size of C. gariepinus. Pennycuick [16], and Amundsen et al. [21] stated that large fish represent greater targets for the ectoparasites and parasites dependent on skin penetration; and that larger fish also circulate more water over their gills and oral cavity than do smaller fish, thus bringing more ectoparasites and cercariae into contact with them. This argument may account for the high prevalence and mean intensity of ectoparasites and larval digeneans in larger fish observed in the present study.

Furthermore, it has been suggested that a prolonged life span of the parasite may contribute to maintain a basic infection level within the host population, and thus act as a stabilizing factor for the parasite population as it will contribute infective stages for the next generation of fish [21]. It is therefore to be expected that there will be a steady increase in the mean intensity of parasites with increase in size of fish. However this was not always the case in the present study as heavily infected fish were not always the largest ones [24]. Morphological and behavioural changes, and development of immunity in older fish that would render them less accessible to invading parasites have been cited as possible causes of the lower intensity often observed in large fish [21].

Irrespective of the variations described for the individual parasite species with fish size, the total parasite burden was greatest in the largest fish. The mean number of parasite species also increased with fish size initially then decreased in larger fish, probably due to development of immunity towards certain parasite species and/ or behavioural and diet changes in large and old fish. Similar observations and conclusions have been reached in other studies [24].

\subsection{Frequency Distribution of the Parasites of Clarias gariepinus}

Most of the parasites recovered from C. gariepinus at the three localities sampled showed an overdispersed distribution. The dispersion index like mean intensity presented two patterns with respect to host size. The first pattern was that of an initial increase in overdispersion followed by a decline in fish over $40 \mathrm{~cm}$ and the second was a continuous rise in dispersion index with host size. The decline of the dispersion index accompanied by a decreased mean abundance may be suggestive of parasite-induced host mortality [26].

When the distribution of parasites is overdispersed a large number of parasites are accommodated in a smaller number of hosts. It should also be noted that most parasites are harmful to their host and the more parasites there are in a host the larger are the adverse effects. With an overdispersed distribution there will be a smaller number of hosts with many parasites and these may die and reduce the parasite population by many more individuals than it does the host population and hence the infection is kept to a moderate level (density-dependent regulation) [24]. On the other hand heavily infected fish may be eaten by a predator; this is advantageous to the parasite if it requires its host to be eaten by another host for the parasite to develop to the next stage of the life cycle [27]. However, if there are few hosts with large numbers of parasites then the chances for the predator finding these will be slight even if susceptibility to predation is greatly increased. There is thus an optimum shape for the distribution in which a large number of the parasites is in a fairly small number of the hosts [28]. Thus with overdispersed distribution the effect of the parasites on the host population is minimal and the distribution is advantageous to both host and parasite in ensuring continuous development of the parasite with minimal losses to the host population.

Overdispersion has been attributed to the heterogeneous distribution of the infective stages of the parasites such that when a fish visits such lacunae with infective stages of parasites, it results in heavy infections. Also behavioural differences and/or genetic factors and random continuous re-exposure of fish to infection over time have been cited as attributing factors to overdispersion [29].

\subsection{Seasonality of Abundance and Frequency Distribution of Parasites}

Results showed that mean intensity and prevalence of all parasites (with the exception of $D$. mashonense, whose prevalence was almost constant throughout the study period), varied with the seasons in all localities sampled. The mean intensity and prevalence of parasites using C. gariepinus as an intermediate host (D. mashonense, Tylodelpys species, Contracaecum species and Clinostomum species) were high during the rain season and tended to decline in the dry season. However mean intensity and prevalence of Tylodelphys sp. at Malimbe were low during the rain season. Fluctuations in prevalence and mean intensity of parasites such as metacercariae of trematodes, which utilize snails as first intermediate hosts, could be attributed to the fluctuations in the population of their snail intermediate hosts in the shores of the Mwanza Gulf. These shores are characterized by seasonal flood plains fringed with marshes and vegetational cover. Concentrations of snails are high in the flood plain 
pools during the dry season, but infectivity in C. gariepinus is low due to the water-land barrier separating fish from these intermediate hosts in the pools. At the onset of the rain season the snails are washed into the shores of the main lake where the parasite infective stages come into contact with C. gariepinus, hence resulting in high prevalence and mean intensity.

Also C. gariepinus is known to traverse long distances into the wetlands where they may be trapped in the pools of water at the onset of the dry season and predated by piscivorous birds, with subsequent removal of parasites from the pool. This could also account for the seasonal variations observed. Nkwengulila [29] reported increased prevalence and mean intensity of the parasites of Clarias species during the dry season contrary to the results of the present study. These seemingly contradictory observations might be attributed to the differences in the size and nature of the water bodies involved. Nkwengulila [29] studied D. mashonense in C. gariepinus from Mindu Dam in Tanzania. The volume of water in small water bodies tends to decline in the dry season; consequently contact between parasites and fish hosts is increased. This is probably not the case in large water bodies like Lake Victoria whose volume of water remains almost constant throughout the year. The intermediate hosts for some of the parasite's infective stages, such as snails, tend to accumulate in the shallow waters of lakes [30], mainly in the pools of the nearby wetlands. Contact between fish and the intermediate hosts of the parasite infective stages is thus blocked during the dry season and is only re-established at the onset of the rain season as discussed above.

Parasites using C. gariepinus as a definitive host showed high prevalence and mean intensity during the dry season. It should be noted that the intermediate hosts for most of these parasites are the planktonic crustaceans and aquatic insects, and that most are acquired through the food chain. In the dry season, concentration of planktonic crustaceans, aquatic insects and zoobenthic organisms is high along the shores of Lake Victoria. It has been demonstrated that zooplankton accumulates in the littoral shallow waters due to accelerated reproduction; in addition embryonic development and hatching of parasite eggs occur along the shallow waters [30]. The presence of the definitive hosts (fish) in synchrony with the increased density of parasite's intermediate hosts leads to increased frequency of contact between the fish hosts and the infective stages of the parasites, thereby increasing prevalence and mean intensity in the fish host.

\section{Acknowledgements}

Thanks are extended to Lake Victoria Environmental Management Project (LVEMP) and Lake Victoria research initiative (VicRes) for financial support and TAFIRI Mwanza centre for technical staffs and laboratory space and the University of Dar es Salaam for availing time to conduct this study.

\section{References}

[1] Eschmeyer, W.N. (2014) Catalog of Fishes: Genera, Species, References. http://research.calacademy.org/research/ichthyology/catalog/fishcatmain.asp

[2] Eccles, D.H. (1992) FAO Species Identification Sheets for Fishery Purposes. Field Guide to the Freshwater Fishes of Tanzania. UNDP Project URT/87/016, Rome, 145 p.

[3] Skelton, P. (1993) A Complete Guide to the Freshwater Fishes of Southern Africa. Southern Book Publishers (Pty) Ltd., Halfway House, 388 p.

[4] Khalil, L.F. and Thurston, J.P. (1973) Studies on the Helminth Parasites of Freshwater Fishes of Uganda including the Descriptions of Two New Species of Digeneans. Revue de Zoologice et Botanice Africaines, 87, 210-247.

[5] Paperna, I. (1980) Parasites, Infections and Diseases of Fish in Africa. CIFA Technical Paper No. 7, 216 p.

[6] Mwita, C. and Nkwengulila, G. (2004) Parasites of Clarias gariepinus (Burchell, 1822) (Pisces: Clariidae) from the Mwanza Gulf, Lake Victoria. Tanzania Journal of Science, 30, 53-62.

[7] Agnese, J.F. and Teugels, G.G. (2001) The Bathyclarias-Clarias Species Flock. A New Model to Understand Rapid Speciation in African Great Lakes. Comptes Rendus de l'Academie des Sciences de Paris, Sciences de la vie, 34, 683-688.

[8] Musiba, M.J. (2004) Some Aspects of the Life History of Diplostomum Species (Digenea: Diplostomatidae) Infecting Clarias Species (Clariidae) of Lake Victoria. M.Sc. Thesis, University of Dar-es-Salaam, 100 p.

[9] Agnese, J.F. and Teugels, G.G. (2005) Insight into the Phylogeny of African Clariidae (Teleostei: Siluriformes): Implications for Their Body Shape Evolution, Biogeography and Taxonomy. Molecular Phylogenetics and Evolution, 36, 546-553. http://dx.doi.org/10.1016/j.ympev.2005.03.028 
[10] Moravec, F., Nasincova, V. and Scholz, T. (1991) Training Course on Fish Parasites: Methods of Investigation of Endoparasitic Helminths. Institute of Parasitology, Czechoslovak Academy of Science.

[11] Moravec, F., Nasincova, V. and Scholz, T. (1991) Training Course on Fish Parasites: Demonstration and Determination of Monogenea. Institute of Parasitology, Czechoslovak Academy of Sciences, $52 \mathrm{p}$.

[12] Chandler, M., Chapman, L.J. and Chapman, C.A. (1995) Patchiness in the Abundance of Metacercariae Parasitizing Poecilia gillii (Poeciliidae) Isolated in Pools of Intermittent Tropical Stream. Environmental Biology of Fishes, 42, 313-321. http://dx.doi.org/10.1007/BF00004925

[13] Margolis, L., Esch, G.W., Holmes, J.C., Kuris, A.M. and Schad, G.A. (1982) The Use of Ecological Terms in Parasitology (Report of an Ad Hoc Committee of the American Society of Parasitologists). The Journal of Parasitology, 68, 131-133. http://dx.doi.org/10.2307/3281335

[14] Byrne, C.J., Holland, C. and Tully, O. (1999) Metazoan Parasites Community Structure of Sea Trout on the West Coast of Ireland. Journal of Fish Biology, 55, 127-134. http://dx.doi.org/10.1111/j.1095-8649.1999.tb00662.x

[15] Shotter, R.A. (1980) Aspects of the Parasitology of the Catfish Clarias anguillaris, L. from a River and a Lake at Zaria, Kaduna State, Nigeria. Bulletin de l'Institut Fondamental d'Afrique Noire, Série A, Sciences Naturelles, 42, 837-859.

[16] Pennycuick, L. (1971) Quantitative Effects of Three Species of Parasites on a Population of Three-Spined Sticklebacks, Gasterosteus aculeatus. Journal of Zoological Society of London, 165, 143-162. http://dx.doi.org/10.1111/j.1469-7998.1971.tb02179.x

[17] Reimchen, T.E. (2001) Ecological Causes of Sex-Biased Parasitism in Three-Spined Stickleback. Biological Journal of the Linnean Society of London, 73, 51-63.

[18] Bell, G. and Burt, A. (1991) The Comparative Biology of Parasite Species Diversity: Internal Helminths of Freshwater Fish. Journal of Animal Ecology, 60, 1047-1063. http://dx.doi.org/10.2307/5430

[19] Kennedy, C.R. (1990) Helminth Communities in Freshwater Fish: Structured Communities of Stochastic Assemblages? In: Esch, G., Bush, A. and Aho, J., Eds., Parasite Communities: Pattern and Processes, Chapman and Hall, London, 131-156. http://dx.doi.org/10.1007/978-94-009-0837-6_6

[20] Aloo, P.A. (2002) A Comparative Study of Helminth Parasites from the Fish Tilapia zillii and Orechromis leucostictus in Lake Naivasha and Oloidien Bay, Kenya. Journal of Helminthology, 76, 95-102. http://dx.doi.org/10.1079/JOH2001105

[21] Amundsen, P.-A., Kristoffersen, R., Knudsen, R. and Klemetsen, A. (1997) Infection of Salmincola edwardsii (Copepoda: Lernaeopodidae) in an Age-Structured Population of Arctic Charr-A Long-Term Study. Journal of Fish Biology, 51, 1033-1046.

[22] Køie, M. (1999) Metazoan Parasites of Flounder Platichthys flesus (L.) along a Transect from the Southwestern to the Northeastern Baltic Sea. ICES Journal of Marine Science, 56, 157-163. http://dx.doi.org/10.1006/jmsc.1999.0463

[23] Tolonen, A., Rita, H. and Peltonen, H. (2000) Abundance and Distribution of Diphyllobothrium ditremum Creplin (Cestoda: Pseudophyllidae) Plerocercoids in Benthic Whitefish, in Northern Finnish Lapland. Journal of Fish Biology, 57, 15-28. http://dx.doi.org/10.1111/j.1095-8649.2000.tb00772.x

[24] Poulin, R. (2000) Variation in the Intraspecific Relationship between Fish Length and Intensity of Parasitic Infection: Biological and Statistical Causes. Journal of Fish Biology, 56, 123-137. http://dx.doi.org/10.1111/j.1095-8649.2000.tb02090.x

[25] Brown, A.F. (1986) Evidence for Density-Dependent Establishment and Survival of Pomphorhynchus laevis (Muller, 1776) (Acanthocephala) in Laboratory-Infected Salmo gairdneri Richardson and Its Bearing on Wild Populations in Leuciscus cephalus (L.). Journal of Fish Biology, 28, 659-669. http://dx.doi.org/10.1111/j.1095-8649.1986.tb05201.x

[26] Kennedy, C.R. (1984) The Use of Frequency Distributions in an Attempt to Detect Host Mortality Induced by Infection of Diplostomatid Metacercariae. Parasitology, 89, 209-220. http://dx.doi.org/10.1017/S0031182000001244

[27] Anderson, R.M. and Gordon, D.M. (1982) Processes Influencing the Distribution of Parasite Numbers within Host Populations with Special Emphasis on Parasite-Induced Host Mortalities. Parasitology, 85, 373-398. http://dx.doi.org/10.1017/S0031182000055347

[28] Pennycuick, L. (1971) Differences in the Parasites Infections in Three-Spined Sticklebacks, Gasterosteus aculeatus, L., of Different Sex, Age and Size. Parasitology, 63, 407-418. http://dx.doi.org/10.1017/S0031182000079932

[29] Nkwengulila, G. (1995) Epidemiology and Taxonomy of Diplostomum Species (Trematoda: Diplostomatidae) Infecting Fish of Llyn Tegid, North Wales and Ruvu Basin-Tanzania. Ph.D. Thesis, University of Liverpool, Liverpool, 321 p.

[30] Marcogliese, D.J. (1995) The Role of Zooplankton in the Transmission of Helminth Parasites to Fish. Reviews in Fish Biology and Fisheries, 5, 336-371. http://dx.doi.org/10.1007/BF00043006 
Scientific Research Publishing (SCIRP) is one of the largest Open Access journal publishers. It is currently publishing more than 200 open access, online, peer-reviewed journals covering a wide range of academic disciplines. SCIRP serves the worldwide academic communities and contributes to the progress and application of science with its publication.

Other selected journals from SCIRP are listed as below. Submit your manuscript to us via either submit@scirp.org or Online Submission Portal.
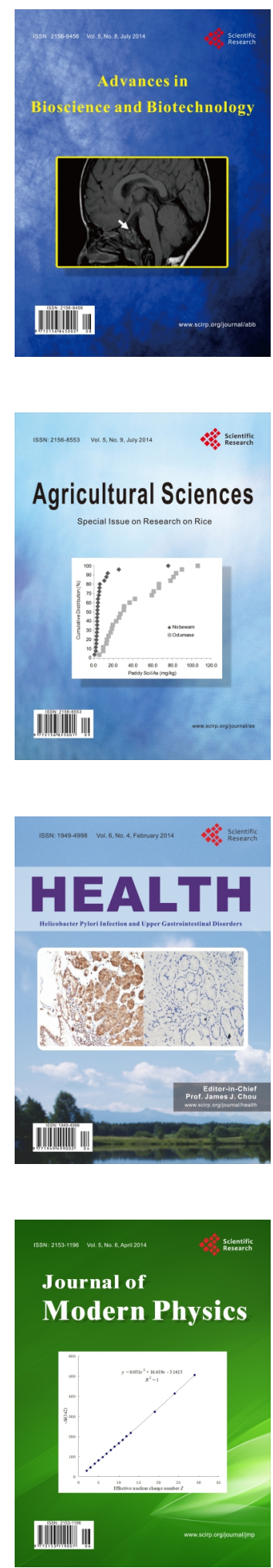
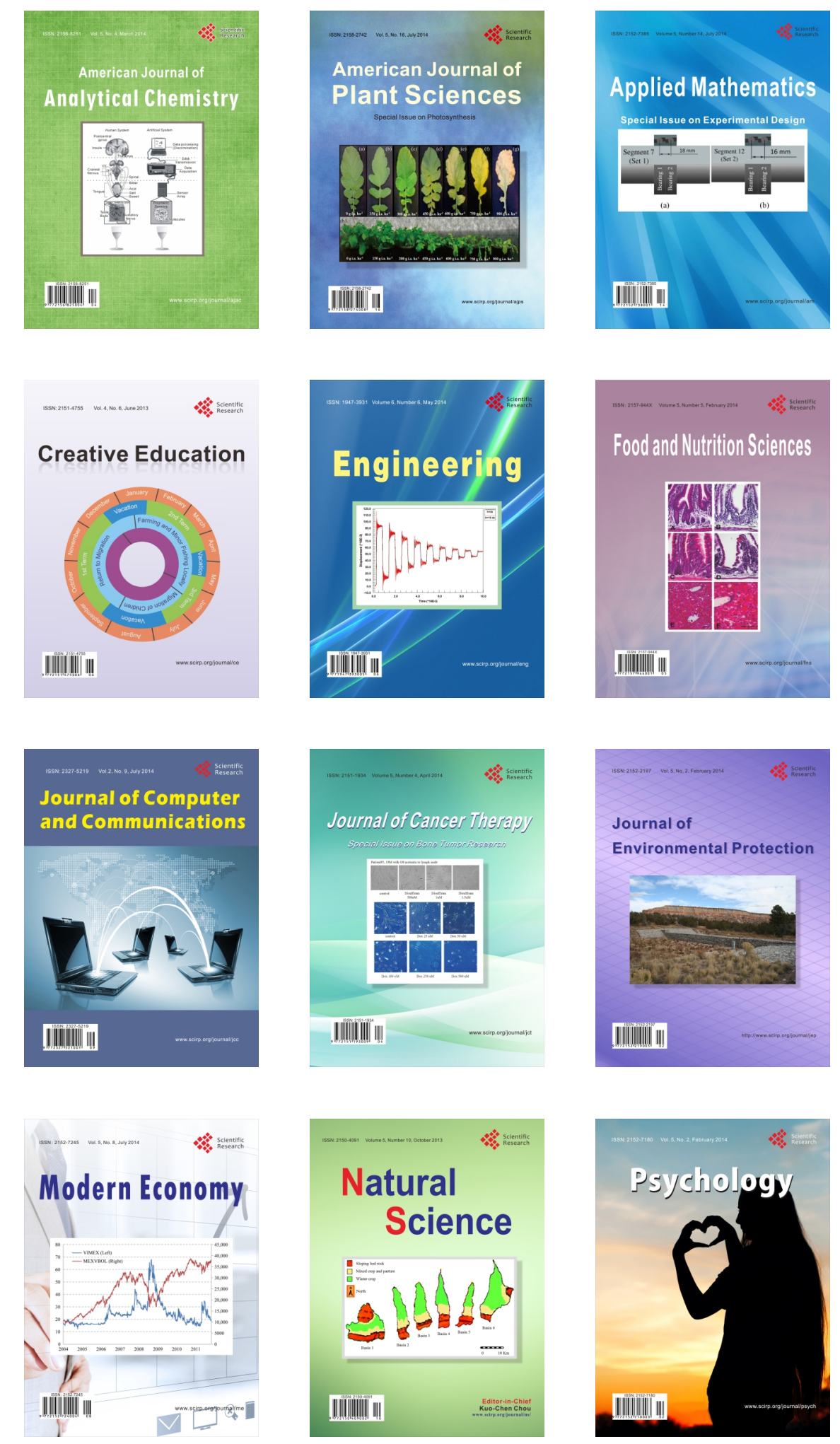